\begin{tabular}{|l|l|l||}
\hline \multicolumn{2}{|c|}{ PublisherInfo } \\
\hline \hline PublisherName & $:$ & BioMed Central \\
\hline \hline PublisherLocation & $:$ & London \\
\hline \hline PublisherImprintName & $:$ & BioMed Central \\
\hline \hline
\end{tabular}

\title{
Probing E. coli
}

\begin{tabular}{|l|l|l||}
\hline \multicolumn{2}{|c|}{ ArticleInfo } \\
\hline \hline ArticleID & $:$ & 3852 \\
\hline \hline ArticleDOI & $:$ & $10.1186 /$ gb-spotlight-20001205-02 \\
\hline \hline ArticleCitationID & $:$ & spotlight-20001205-02 \\
\hline \hline ArticleSequenceNumber & $:$ & 289 \\
\hline \hline ArticleCategory & $:$ & Research news \\
\hline \hline ArticleFirstPage & $:$ & 1 \\
\hline \hline ArticleLastPage & $:$ & 2 \\
\hline \hline & & RegistrationDate : 2000-12-05 \\
ArticleHistory & $:$ & OnlineDate $\quad$ 2000-12-05 \\
\hline \hline ArticleCopyright & $:$ & BioMed Central Ltd2000 \\
\hline \hline ArticleGrants & $:$ & \\
\hline \hline ArticleContext & $:$ & 130591111 \\
\hline \hline
\end{tabular}




\section{William Wells}

Email: wells@biotext.com

In the December Nature Biotechnology Selinger et al. use an Escherichia coli oligonucleotide array with 30-base-pair resolution to detect antisense transcripts, new open reading frames (ORFs), and transcription starts and stops (Nat Biotechnol 2000, 18:1262-1268). The 295,936 elements of the array do not come without their problems. The sheer size and complexity of the array means that there is a huge amount of cross hybridization detected by missense probes. But the use of many probes within the same gene allows Selinger et al. to identify many genes that are up- or down-regulated in stationary phase. They also confirm transcription stop and start sites for two genes. Scanning for antisense transcripts suggests that there is a low level of transcription throughout the genome, probably from replication-induced and readthrough transcription.

\section{References}

1. Nature Biotechnology, [http://www.nature.com/nbt/]

This PDF file was created after publication. 